\title{
PENGARUH FIRM SIZE, PROFITABILITY, FIRM AGE, FIRM GROWTH, LEVERAGE, DAN INDEPENDENT COMMISSIONER TERHADAP INTELLECTUAL CAPITAL DISCLOSURE PADA PERUSAHAAN SEKTOR KEUANGAN YANG TERDAFTAR DI BURSA EFEK INDONESIA PADA TAHUN 2012-2014
}

\author{
Monica Joson dan Merry Susanti \\ Fakultas Ekonomi Universitas Tarumanagara \\ monicamone94@gmail.com; m3r2y@yahoo.com
}

\begin{abstract}
The purpose of this study is to analyze the effect of firm size, profitability, firm age, firm growth, leverage and independent commissioner on intellectual capital disclosure of financial companies which are registered in Indonesia Stock Exchange from 2012-2014. The samples of this study are 57 companies. Secondary data are collected by learning the company's financial statement. Collected data were processed by using SPSS for Windows 20. The result showed that firm size, firm age and independent commissioner partially influence the intellectual capital disclosure, while profitability, firm growth and leverage has no effect on intellectual capital disclosure.
\end{abstract}

Keywords: firm size, profitability, firm age, firm growth, leverage and independent commissioner

\begin{abstract}
Abstrak: Tujuan penelitian ini adalah untuk menganalisis pengaruh firm size, profitability, firm age, firm growth, leverage dan independent commissioner terhadap intellectual capital disclosure secara parsial. Populasi dalam penelitian ini adalah perusahaan sektor keuangan yang terdaftar di Bursa Efek Indonesia pada tahun 2012-2014. Sampel dalam penelitian ini berjumlah 57 perusahaan. Data sekunder diperoleh dengan mempelajari laporan keuangan perusahaan. Data yang telah diperoleh kemudian diolah dengan menggunakan software SPSS for Windows 20. Hasil penelitian ini menunjukkan bahwa firm size, firm age dan independent commissioner berpengaruh secara parsial terhadap intellectual capital disclosure, sedangkan profitability, firm growth dan leverage secara parsial tidak berpengaruh terhadap intellectual capital disclosure.
\end{abstract}

Kata kunci: ukuran perusahaan, profitabilitas, umur perusahaan, pertumbuhan perusahaan, leverage dan komisioner independen

\section{PENDAHULUAN}

Dalam era globalisasi ini, perkembangan teknologi informasi dan pengetahuan mendorong munculnya new economy, yang biasa dikenal dengan knowledge-based economy, dimana modal intelektual didefinisikan sebagai sumber daya perusahaan sehingga perusahaan berkembang menjadi berbasis ilmu pengetahuan. Perkembangan teknologi informasi mendorong peningkatan inovasi dan ilmu pengetahuan dalam dunia industri yang pada akhirnya akan menciptakan nilai dalam perusahaan. Hal ini yang menjadikan kompetisi antar perusahaan bukan hanya dalam kepemilikan mesin-mesin industri yang canggih, tetapi kepada inovasi, informasi, dan pengetahuan sumber daya manusia yang dimilikinya. 
Oleh karena itu, perusahaan diharapkan dapat tetap bertahan dan berkembang dalam menghadapi kompetisi global. Untuk ini, perusahaan perlu melakukan pengungkapan untuk menciptakan nilai tambah bagi perusahaan, yaitu intangible asset untuk mempertahankan posisi perusahaan di pasar.

Namun karena belum adanya standar untuk menetapkan item-item apa saja yang termasuk dalam intangible assets (aset tak berwujud) yang dapat dikelola, diukur, dan dilaporkan sehingga ini menjadi masalah dalam pengakuan intangible assets. Alternatif yang diusulkan untuk memperluas pengungkapan intangible assets adalah melalui pengungkapan modal intelektual, untuk memberi lebih banyak informasi yang memungkinkan perusahaan memiliki pandangan yang sama terhadap penciptaan nilai (Sir, Subroto dan Chandrarin, 2010).

Pengungkapan modal intelektual atau intellectual capital disclosure dalam laporan tahunan akan memberikan banyak manfaat bagi perusahaan, seperti membantu perusahaan dalam memformulasikan strategi, menilai strategi perusahaan, membantu proses pembuatan keputusan ekspansi dan diversifikasi, serta digunakan sebagai dasar untuk menentukan kompensasi bagi external stakeholders (Taliyang, Latif dan Mustafa, 2011). Dalam hal ini, manajer perusahaan perlu mempertimbangkan intellectual capital disclosure dalam laporan tahunan perusahaan dimana manajer bertanggung jawab untuk menyediakan laporan mengenai kondisi perusahaan termasuk sumber daya intelektual yang dimiliki oleh perusahaan sebagai suatu bentuk pertanggungjawaban bagi stakeholders. Intellectual capital disclosure merupakan informasi yang bernilai bagi investor dimana dapat membantu mengurangi ketidakpastian mengenai prospek ke depan dan memfasilitasi ketepatan penilaian terhadap perusahaan (Bukh, 2003 di dalam Suhardjanto dan Wardhani, 2010).

Intellectual capital terdiri dari tiga elemen, yaitu human capital yang mencakup sumber daya manusia, structural capital yang meliputi kemampuan perusahaan dalam menjalankan rutinitas perusahaan, dan relational capital yang menggambarkan hubungan baik antara perusahaan dengan external stakeholders (Suhardjanto dan Wardhani, 2010). Ketiga elemen tersebut diharapkan diungkapkan dalam laporan tahunan perusahaan.

Di Indonesia, rata-rata jumlah elemen intellectual capital yang diungkapkan dalam laporan tahunan perusahaan publik di Indonesia adalah sebesar 56\% (Purnomosidhi, 2006). Hal ini berarti belum semua perusahaan mengungkapkan modal intelektual dalam laporan tahunan.

Penelitian yang menguji faktor-faktor yang mempengaruhi pengungkapan intellectual capital telah banyak dilakukan. Penelitian yang dilakukan Nugroho (2012) di perusahaan sektor perbankan, memperoleh hasil bahwa firm size tidak memiliki pengaruh yang signifikan terhadap intellectual capital disclosure. Hasil penelitian tersebut bertentangan dengan penelitian yang dilakukan Lina (2013) di sektor industri perbankan, telekomunikasi, eletronik, komputer dan multimedia, otomotif, dan farmasi. Penelitian tersebut menguji firm size sebagai salah satu faktor intellectual capital disclosure. Hasilnya menunjukkan bahwa firm size memiliki pengaruh positif terhadap intellectual capital disclosure.

Suhardjanto dan Wardhani (2010) melakukan penelitian terhadap perusahaan Indonesia yang terdaftar di BEI, dimana hasil penelitiannya adalah profitability berpengaruh signifikan positif terhadap intellectual capital disclosure. Taliyang, Latif dan Mustafa (2011) melakukan penelitian terhadap perusahaan yang terdaftar di Bursa Malaysia yang mencakup lima sektor industri dan menemukan bahwa firm growth 
memiliki pengaruh yang signifikan terhadap intellectual capital disclosure. Tetapi, Lina (2013) yang juga menguji tentang profitability dan firm growth, memperoleh hasil yang berbeda dimana profitability dan firm growth tidak memiliki pengaruh terhadap intellectual capital disclosure.

Stephani dan Yuyetta (2011) juga meneliti tentang firm age dan leverage, dimana hasil penelitian menunjukkan bahwa firm age tidak memiliki pengaruh yang signifikan terhadap intellectual capital disclosure dan leverage memiliki pengaruh signifikan positif terhadap intellectual capital disclosure. Hasil ini berbeda dengan Taliyang, Latif dan Mustafa (2011) yang menemukan bahwa firm age memiliki pengaruh signifikan terhadap intellectual capital disclosure. Tetapi, hasil penelitian yang dilakukan Nugroho (2012) menemukan bahwa leverage tidak memiliki pengaruh yang signifikan terhadap intellectual capital disclosure.

White, Lee dan Tower (2007) memperoleh hasil bahwa komisaris independen memiliki pengaruh signifikan terhadap intellectual capital disclosure. Suhardjanto dan Wardhani (2010) serta Nugroho (2012) yang juga menguji tentang independent commissioner, ternyata tidak berhasil memperoleh bukti yang menunjukkan adanya pengaruh independent commissioner terhadap intellectual capital disclosure.

\section{KAJIAN TEORI}

Agency Theory. Agency theory (teori keagenan) menjelaskan hubungan kontrak antara manajer yang disebut agent dan pemilik perusahaan yang dianggap sebagai principal, seperti yang dikatakan oleh Scott (2014): "Agency theory is a branch of game theory that studies the design of contracts to motivate a rational agent to act on behalf of a principal when the agent's interest would otherwise conflict with those of the principal". Menurut Suhardjanto dan Wardhani (2010), Agency Theory mengandung pengungkapan sebagai mekanisme yang dapat mengurangi biaya yang dihasilkan dari konflik antara manajer dengan pemegang saham (compensation contracts) dan dari konflik antara perusahaan dan kreditornya (debt contract). Hal ini berarti pengungkapan merupakan mekanisme yang digunakan untuk mengontrol kinerja manajer dan mendorong manajer untuk mengungkapkan voluntary information seperti intellectual capital disclosure.

Menurut Schroeder, Clark, dan Cathey (2013), asumsi dari teori keagenan adalah masing-masing individu berusaha untuk memaksimalkan kepentingan mereka sendiri, "...the shareholders cannot observe all of the actions and decisions made by the agents, so a threat exist that the agents will act to maximize their own wealth rather than that of the stockholders." Hal ini dapat menyebabkan konflik kepentingan antara manajer dan shareholders, dimana kepentingan manajer tidak sejalan dengan kepentingan para pemegang saham. Shareholders menginginkan untuk memaksimalkan keuntungan atas investasi mereka di perusahaan sedangkan manajer mungkin memaksimalkan kepentingan mereka sendiri dengan mengorbankan para pemegang saham.

Intellectual Capital Disclosure. Modal intelektual didefinisikan sebagai pengetahuan dan aset tidak berwujud lainnya yang menghasilkan atau menciptakan baik nilai saat ini maupun nilai di masa depan (Viedma, 2007 dalam Lina, 2013). Pengungkapan modal intelektual dapat bermanfaat untuk menginformasikan kepada pemangku kepentingan (stakeholders) atas sumber daya intelektual yang dimiliki oleh suatu perusahaan dan dapat meminimalkan asimetri informasi. Manfaat bagi perusahaan berarti bahwa pengetahuan 
tersebut mampu menyumbangkan sesuatu atau memberikan kontribusi yang dapat memberi nilai tambah dan kegunaan yang berbeda bagi perusahaan (Santosa dan Setiawan, 2010 dalam Lina, 2013).

Canibano et al. (1999) dalam Bruggen, Vergauwen, dan Dao (2009) menyatakan bahwa:

"Furthermore, IC disclosure can help to increase the value relevance of financial statements. Failures to provide relevant information about intellectual capital may lead to a deterioration of the company's financial position and a loss of competitiveness in the long run."

Bruggen, Vergauwen, dan Dao (2009) juga mengatakan bahwa:

"Voluntary disclosure is especially important in the knowledge based company where substantial amounts of money are invested in intangible assets and intellectual capital, which are not fully recognized on the financial statements."

Pengaruh Firm Size terhadap Intellectual Capital Disclosure. Consoladi et al. di dalam Oktavianti dan Wahidahwati (2014), menyatakan bahwa ukuran perusahaan dapat mempengaruhi kinerja sosial perusahaan karena perusahaan yang besar mempunyai pandangan yang lebih jauh, sehingga lebih berpartisipasi dalam menumbuhkan kinerja sosial perusahaan. Semakin besar ukuran perusahaan, semakin tinggi pula tuntutan terhadap keterbukaan informasi dibanding perusahaan yang lebih kecil.

Ada beberapa alasan yang menjelaskan mengapa perusahaan besar mempertimbangkan untuk mengungkapkan intellectual capital. Alasan pertama, perusahaan besar memiliki sumber daya untuk mengungkapkan lebih banyak informasi. Kedua, perusahaan besar memiliki sistem informasi manajemen internal yang lebih baik sebagai hasil dari berbagai kegiatan perusahaan, sehingga sanggup untuk mengungkapkan lebih banyak informasi (Ferreira, Branco dan Moreira, 2012).

Penelitian yang dilakukan oleh Purnomosidhi (2006) menunjukkan bahwa size berpengaruh terhadap pengungkapan intellectual capital. Hasil penelitian ini diperkuat oleh penelitian yang dilakukan oleh White, Lee, dan Tower (2007), Bruggen, Vergauwen, dan Dao (2009), Windri dan Januarti (2010), Suhardjanto dan Wardhani (2010), Taliyang, Latif dan Mustafa (2011), Stephani dan Yuyetta (2011), Ferreira, Branco, dan Moreira (2012), Lina (2013), serta Oktavianti dan Wahidahwati (2014). Tetapi penelitian yang dilakukan oleh Nugroho (2012) serta Sudarmadji dan Sularto (2007) ternyata tidak berhasil menunjukkan adanya pengaruh ukuran perusahaan terhadap intellectual capital disclosure.

H1: Firm Size berpengaruh terhadap intellectual capital disclosure

Pengaruh Profitability terhadap Intellectual Capital Disclosure. Menurut Kieso, Weygandt dan Kimmel (2013) kegunaan dari rasio profitabilitas adalah: "Profitability ratio measure the income or operating success of a company for a given period of time."

Menurut Fahmi (2014), pengertian profitabilitas adalah sebagai berikut:

"Rasio ini mengukur efektivitas manajemen secara keseluruhan yang ditujukan oleh besar kecilnya tingkat keuntungan yang diperoleh dalam hubungannya dengan penjualan maupun investasi. Semakin baik rasio profitabilitas maka semakin menggambarkan kemampuan tingginya perolehan keuntungan perusahaan." 
Berdasarkan beberapa definisi di atas dapat disimpulkan bahwa semakin baik rasio profitabilitas maka semakin dapat menggambarkan kemampuan perusahaan dalam perolehan keuntungan.

Menurut Watts dan Zimmerman (1978) dalam Ferreira, Branco, dan Moreira (2012), perusahaan yang mendapatkan keuntungan, kemungkinan besar akan melakukan pengungkapan sukarela untuk menyampaikan informasi kepada stakeholders bahwa perusahaan memiliki keunggulan dibandingkan dengan perusahaan lainnya sehingga dapat mengurangi biaya politik.

Hasil penelitian yang dilakukan oleh Suhardjanto dan Wardhani (2010) serta Oktavianti dan Wahidahwati (2014) menunjukkan adanya pengaruh profitabilitas terhadap intellectual capital disclosure. Purnomosidhi (2006) serta Sudarmadji dan Sularto (2007) tidak berhasil memperoleh bukti empiris bahwa profitabilitas berpengaruh terhadap intellectual capital disclosure. Hasil penelitian ini didukung oleh Taliyang, Latif dan Mustafa (2011) yang melakukan penelitian di Malaysia dan tidak berhasil menemukan adanya pengaruh profitabilitas terhadap intellectual capital disclosure. Peneliti lain seperti: Stephani dan Yuyetta (2011), Ferreira, Branco, dan Moreira (2012), serta Lina (2013) juga menemukan hasil yang sama.

H2: Profitability berpengaruh terhadap intellectual capital disclosure

Pengaruh Firm Age terhadap Intellectual Capital Disclosure. Menurut Wijana, Achsin dan Wirakusuma (2013), umur perusahaan menunjukkan tingkat kedewasaan suatu perusahaan. Perusahaan akan melakukan perbaikan pada informasi yang diungkapkan dari waktu ke waktu. Bertambahnya usia perusahaan menunjukkan bahwa pengungkapan juga berkembang. Semakin lama eksistensi perusahaan dalam bisnis akan memotivasi perusahaan untuk meningkatkan pengungkapan (stakeholder theory). Semakin panjang umur perusahaan akan memberikan pengungkapan informasi keuangan yang lebih luas dibandingkan perusahaan lain yang umurnya lebih pendek dengan alasan perusahaan tersebut memiliki pengalaman lebih dalam pengungkapan laporan tahunan (Wallace, Naser, dan Mora, 1994 dalam Lina, 2013). Dari penjelasan di atas dapat disimpulkan bahwa, perusahaan dengan umur yang panjang telah dianggap dewasa dan akan lebih luas dalam melakukan pengungkapan.

Tetapi, Ulum (2009) berpendapat bahwa semakin lama umur perusahaan belum tentu semakin baik tingkat pengalaman dan pemahamannya terkait dengan intellectual capital yang dimiliki oleh suatu perusahaan, sehingga tingkat pengungkapan intellectual capital tidak bisa optimal. Alasan lainnya karena semangat motivasi untuk mendongkrak citra perusahaan dan menjadi perusahaan ternama dalam perdagangan pasar saham meskipun perusahaan mereka baru di kancah pasar modal.

Penelitian terdahulu yang dilakukan oleh White, Lee dan Tower (2007) belum berhasil menemukan adanya pengaruh umur perusahaan terhadap pengungkapan intellectual capital. Hasil penelitian ini didukung oleh Stephani dan Yuyeta (2011) serta Nugroho (2012). Sementara penelitian yang dilakukan oleh Taliyang, Latif dan Mustafa (2011) di Malaysia maupun Lina (2013) yang melakukan penelitian di Indonesia berhasil menemukan adanya hubungan umur perusahaan terhadap pengungkapan intellectual capital.

H3: Firm age berpengaruh terhadap intellectual capital disclosure 


\section{Pengaruh Firm Growth terhadap Intellectual Capital Disclosure}

Perusahaan dalam kondisi bertumbuh memerlukan pengungkapan yang lebih memadai karena dalam hal ini dapat mengurangi terjadinya informasi asimetri (Haniff, Hisham, dan Rashid, 2005 dalam Lina, 2013). Dalam kondisi pertumbuhan, perusahaan akan lebih mengungkapkan berbagai informasi yang dibutuhkan oleh pihak-pihak yang berkepentingan secara lebih rinci.

Hasil penelitian Taliyang, Latif, dan Mustafa (2011) di Malaysia menemukan adanya pengaruh pertumbuhan perusahaan terhadap pengungkapan intellectual capital. Di pihak lain, Lina (2013) tidak berhasil menemukan adanya pengaruh pertumbuhan perusahaan terhadap pengungkapan intellectual capital.

H4: Firm growth berpengaruh terhadap intellectual capital disclosure

Pengaruh Leverage terhadap Intellectual Capital Disclosure. Leverage adalah besarnya aktiva yang diukur dengan pembiayaan hutang yang dilihat dari rasio likuiditas sebagai salah satu ukuran kinerja perusahaan. Menurut Looke dalam Stephani dan Yuyetta (2011), perusahaan yang memiliki leverage yang tinggi cenderung melakukan pengungkapan informasi yang lebih luas kepada pihak yang berkepentingan. Hal ini terjadi karena menurut teori agensi, semakin tinggi tingkat leverage perusahaan maka akan semakin besar pula agency cost yang dikeluarkan dan pengungkapan informasi yang lebih komprehensif akan dilakukan perusahaan untuk mengurangi biaya agensi tersebut.

Hasil penelitian White, Lee dan Tower (2007) menunjukkan adanya pengaruh leverage terhadap pengungkapan intellectual capital. Hasil penelitian ini didukung oleh Stephani dan Yuyetta (2011). Tetapi, hasil penelitian Sudarmadji dan Sularto (2007) menunjukkan hasil yang berbeda, yaitu tidak adanya pengaruh leverage terhadap pengungkapan intellectual capital. Hasil penelitian ini didukung oleh Suhardjanto dan Wardhani (2010), Windri dan Januarti (2010), Taliyang, Latif dan Mustafa (2011), Ferreira, Branco, dan Moreira (2012), Nugroho (2012), serta Oktavianti dan Wahidahwati (2014).

H5: Leverage berpengaruh terhadap intellectual capital disclosure

Pengaruh Independent Commisioner terhadap Intellectual Capital Disclosure. Resource dependence theory (Haniffa dan Cooke, 2005 dalam Li, Pike dan Haniffa, 2008), mengusulkan agar lebih banyak dewan komisaris di dewan selama mereka dapat menyediakan keahlian, prestasi, hubungan yang lebih luas dan memainkan satu peran kunci dalam mempengaruhi pengungkapan. Hal ini diperluas oleh Gibbins et al. (1990) dalam Li, Pike dan Haniffa (2008) yang menyatakan bahwa keahlian dan pengalaman yang lebih luas dari para dewan komisaris akan mendorong manajemen dalam mengambil suatu posisi pengungkapan melewati suatu ketaatan pada aturan keagamaan, ketaatan tanpa kritik pada norma yang ditentukan, pada suatu posisi yang lebih proaktif yang mencerminkan keterkaitan nilai intellectual capital disclosure kepada stakeholders. White, Lee dan Tower (2007) menyatakan jika pengawasan telah dilakukan oleh komisaris independen dengan efektif, maka pengelolaan perusahaan akan dilakukan dengan baik pula, dan manajemen akan mengungkapkan semua informasi yang ada, termasuk informasi tentang intellectual capital.

White, Lee dan Tower (2007) maupun Li, Pike dan Haniffa (2008) dalam penelitiannya menemukan adanya pengaruh komisaris independen terhadap pengungkapan intellectual capital. Tetapi, Suhardjanto dan Wardhani (2010), Nugroho (2012), serta 
Oktavianti dan Wahidahwati (2014) dalam penelitiannya tidak berhasil menemukan adanya pengaruh antara komisaris independen dengan pengungkapan intellectual capital. H6: Independent Commisioner berpengaruh terhadap intellectual capital disclosure

Dari hipotesis yang telah diuraikan, berikut disajikan model penelitian, yaitu:

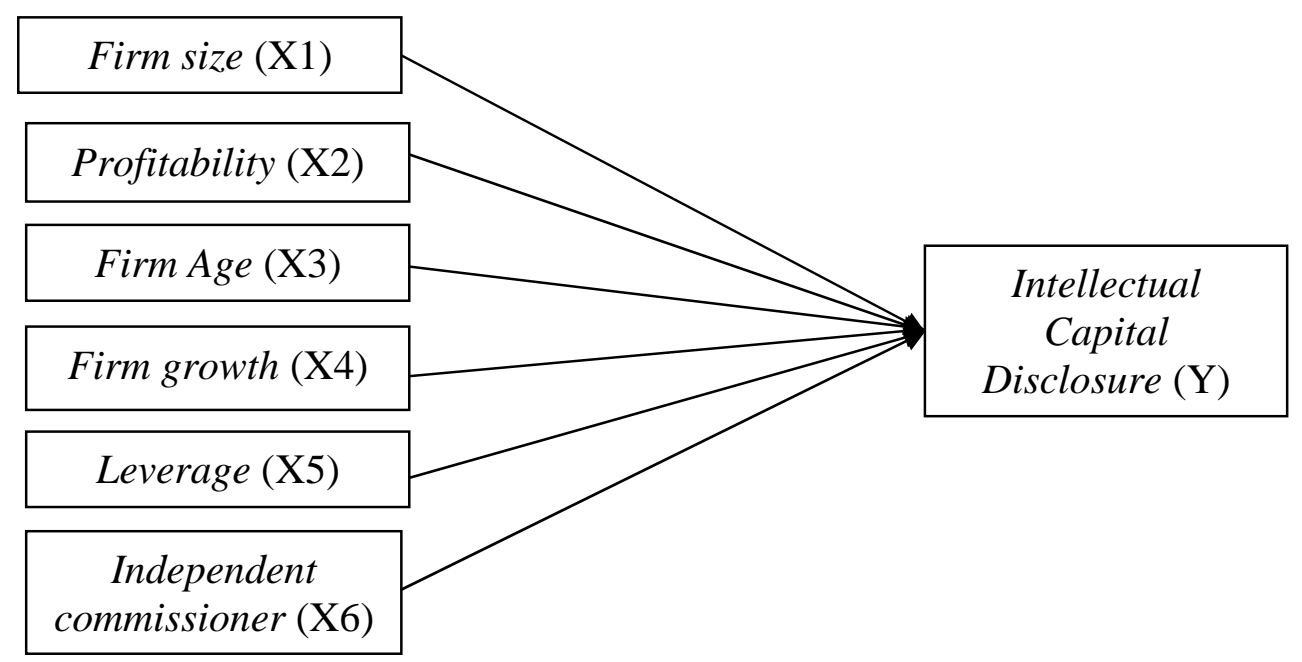

Gambar 1. Model penelitian

\section{METODE}

Sampel dan Data. Populasi dalam penelitian ini adalah perusahaan sektor keuangan yang terdaftar di Bursa Efek Indonesia (BEI) selama periode 2012 sampai dengan 2014. Pemilihan sampel pada penelitian ini dengan menggunakan metode purposive sampling. Perusahaan yang dijadikan sampel adalah perusahaan sektor keuangan yang harus memenuhi kriteria-kriteria tertentu, sebagai berikut: (1) Perusahaan sektor keuangan yang terdaftar di Bursa Efek Indonesia pada tahun 2012-2014; (2) Perusahaan yang tidak mengalami kerugian selama tahun penelitian 2012-2014; (3) Perusahaan sektor keuangan melaporkan informasi yang bersifat moneter dalam satuan mata uang Rupiah; (4) Perusahaan sektor keuangan yang menyajikan data secara lengkap yang diperlukan dalam penelitian.

Identifikasi dan Pengukuran Variabel. Dalam penelitian ini terdapat dua variabel, yaitu variabel dependent dan variabel independent. Variabel dependent dalam penelitian ini adalah intellectual capital disclosure yang diukur menggunakan angka index (ICD Index). Persentase dari index pengungkapan dihitung menurut rumus yang dikemukakan oleh Ferreira, Branco dan Moreira (2012):

$$
\text { Score }=\sum_{i=1}^{m_{j}} d i / N
$$


Dimana: Score = variabel dependen index pengungkapan modal intelektual; $D i=1 \mathrm{jika}$ item diungkapkan dalam laporan tahunan, 0 jika item tidak diungkapkan dalam laporan tahunan; $\mathrm{N}=$ total jumlah item yang diukur (25 items); $m_{j}=$ angka maksimum indikator di yang diungkapkan oleh perusahaan $\mathrm{j}$

Penelitian ini menggunakan index pengungkapan sejumlah 25 items yang dikembangkan oleh Sveiby dalam Purnomosidhi (2006). Index pengungkapan merupakan suatu metode untuk membuat angka pengungkapan informasi tertentu dengan menggunakan 1 untuk setiap item yang diungkapkan dan 0 untuk setiap item yang tidak diungkapkan dalam suatu perusahaan. Berikut disajikan 25 items pengungkapan:

Tabel 1. Intellectual Capital Disclosure Framework

\begin{tabular}{clc}
\hline Keterangan & \multicolumn{1}{c}{ Jenis item } & Kode \\
\hline & Intellectual Property & \\
& Patent & IC 1 \\
& Copyright & IC 2 \\
& Trademarks & IC 3 \\
& Infrastructure assets & \\
Internal Structure & Management Philosophy & IC 4 \\
& Corporate Culture & IC 5 \\
& Information Systems & IC 6 \\
& Management Process & IC 7 \\
& Networking Systems & IC 8 \\
& Research Projects & IC 9 \\
& Brand & EC 1 \\
& Customer & EC 2 \\
External Structure & Customer loyalty & EC 3 \\
(10 items) & Distribution channels & EC 4 \\
& Business Colaboration & EC 5 \\
& Favourable Contracts & EC 6 \\
& Financial Contracts & EC 7 \\
& Licensing agreements & EC 8 \\
& Franchising agreements & EC 9 \\
& Know how & EC 10 \\
& Education & HC 1 \\
(6 items) & Vocational Qualification & HC 2 \\
& Work related- Knowledge & HC 3 \\
& Work related- Competence & HC 4 \\
& Entrepreneurial spirit & HC 5 \\
& HC 6 \\
\hline
\end{tabular}

Sumber: (Sveiby di dalam Purnomosidhi, 2006)

Variabel independen pada penelitian ini ada enam variabel. Pertama adalah firm size (ukuran perusahaan) yang merupakan gambaran besar kecilnya perusahaan yang ditunjukkan dengan nilai total aset yang disajikan dalam neraca akhir tahun. Pada penelitian ini ukuran perusahaan dihitung dengan menggunakan logaritma natural nilai total asset perusahaan (Lina, 2013), sebagai berikut:

Firm size = logarithma natural total asset 
Variabel independen yang kedua adalah profitability. Profitabilitas menunjukkan kinerja manajemen dalam mengelola asset perusahaan untuk menghasilkan profit (Lina, 2013):

$$
\text { Profitability }=\frac{\text { Net Income }}{\text { Total Asset }}
$$

Firm age adalah umur perusahaan. Menurut Stephani dan Yuyetta (2011), umur perusahaan dihitung dari lamanya sejak perusahaan pertama kali listing di Bursa Efek Indonesia (BEI).

Firm growth adalah tingkat pertumbuhan perusahaan yang dapat dihitung menggunakan market to book value ratio yang menunjukkan market price per share dengan value of equity per share (Taliyang, Latif dan Mustafa, 2011), dengan rumus sebagai berikut:

$$
\text { Firm growth }=\frac{\text { Market price per share }}{\text { Value of equity per share }}
$$

Variabel independen selanjutnya adalah Leverage yang merupakan suatu ukuran atas penggunaan hutang untuk membiayai aset perusahaan. Pada penelitian ini leverage dihitung dengan menggunakan (Stephani dan Yuyetta, 2011):

$$
\text { Leverage }=\frac{\text { Total Liabilities }}{\text { Total Assets }}
$$

Variabel independen yang terakhir adalah Independent commisioner yang merupakan perbandingan jumlah komisaris independen dengan total dewan komisaris (Nugroho, 2012):

$$
\text { Independent commisioner }=\frac{\text { Komisaris Independen }}{\text { Total Dewan Komisaris }}
$$

\section{HASIL DAN PEMBAHASAN}

Populasi yang digunakan dalam penelitian ini adalah perusahaan sektor keuangan yang terdaftar di Bursa Efek Indonesia (BEI) selama tahun 2012-2014. Perusahaan sektor keuangan dipilih karena aktivitasnya lebih banyak memanfaatkan intellectual capital dibandingkan industri manufaktur yang lebih banyak menggunakan aset fisik (Firer dan Williams, 2003). Berikut disajikan pengambilan sampel berdasarkan purposive sampling:

Tabel 2. Jumlah sampel penelitian

\begin{tabular}{clc}
\hline No. & \multicolumn{1}{c}{ Keterangan } & Jumlah \\
\hline 1. & $\begin{array}{l}\text { Perusahaan sektor keuangan yang terdaftar di Bursa Efek } \\
\text { Indonesia pada tahun 2012-2014 }\end{array}$ & 67 \\
2. & $\begin{array}{l}\text { Perusahaan yang mengalami kerugian selama tahun } \\
\text { penelitian 2012-2014 }\end{array}$ \\
3. & $\begin{array}{l}\text { Perusahaan sektor keuangan yang tidak melaporkan } \\
\text { informasi yang bersifat moneter dalam satuan mata uang }\end{array}$ \\
Rupiah & $\begin{array}{l}\text { Perusahaan sektor keuangan yang tidak menyajikan data } \\
\text { secara lengkap yang diperlukan dalam penelitian } \\
\text { Jumlah sampel penelitian }\end{array}$ & (2) \\
\hline
\end{tabular}


Berdasarkan Tabel 2 dapat dilihat bahwa sampel penelitian yang memenuhi kriteria adalah sebanyak 57 perusahaan per tahun atau sebanyak 171 data perusahaan selama tiga tahun.

Berikut ini disajikan tabel 3 mengenai statistik deskriptif dari sampel yang digunakan:

Tabel 3. Hasil Pengujian Statistik Deskriptif Tahun 2012-2014

\begin{tabular}{|c|c|c|c|c|c|}
\hline \multicolumn{6}{|c|}{ Descriptive Statistics } \\
\hline & $\mathrm{N}$ & Minimum & Maximum & Mean & Std. Deviation \\
\hline Ukuran & 171 & 24.53094 & 34.38217 & 29.7044075 & 2.42824303 \\
\hline Profitability & 171 & .00044 & .20105 & 0383908 & .03701248 \\
\hline Umur & 171 & 1 & 32 & 13.53 & 7.719 \\
\hline Growth & 171 & .36415 & 8.29660 & 1.6584591 & 1.16994024 \\
\hline Leverage & 171 & .00442 & .92980 & 6800069 & .27627668 \\
\hline Komisaris Independen & 171 & .20000 & 1.00000 & .5208136 & .12538906 \\
\hline $\begin{array}{l}\text { Intellectual Capital } \\
\text { Disclosure }\end{array}$ & 171 & .24 & .76 & .5347 & .11841 \\
\hline Valid N (listwise) & 171 & & & & \\
\hline
\end{tabular}

Berikut disajikan hasil pengujian normalitas:

Tabel 4. Hasil Pengujian Normalitas Tahun 2012-2014

\begin{tabular}{llr}
\hline \multicolumn{2}{c}{ One-Sample Kolmogorov-Smirnov Test } \\
\hline $\mathrm{N}$ & & Unstandardized Residual \\
\hline Normal Parameters & & 171 \\
& Mean & $0 \mathrm{E}-7$ \\
Most Extreme & Std. Deviation & .07746761 \\
Differences & Absolute & .051 \\
Kolmogorov-Smirnov Z & Positive & .049 \\
Asymp. Sig. (2-tailed) & Negative & -.051 \\
\hline a. Test distribution is Normal. & .667 \\
b. Calculated from data. & .765 \\
\hline
\end{tabular}

Dari hasil pengujian di atas, dapat dilihat bahwa nilai signifikansi Kolmogorov-Smirnov Z sebesar 0,765 dimana nilai tersebut lebih besar dari nilai signifikansi 0,05 yang berarti data berdistribusi secara normal. Hal ini berarti bahwa variabel yang digunakan dalam penelitian ini memenuhi syarat normalitas, sehingga data layak digunakan untuk menguji pengaruh firm size, profitability, firm age, firm growth, leverage, dan independent commissioner terhadap intellectual capital disclosure.

Hasil pengujian multikolinieritas atas penelitian ini dapat dilihat dalam tabel 5 sebagai berikut: 
Tabel 5. Hasil Pengujian Multikolinieritas Tahun 2012-2014

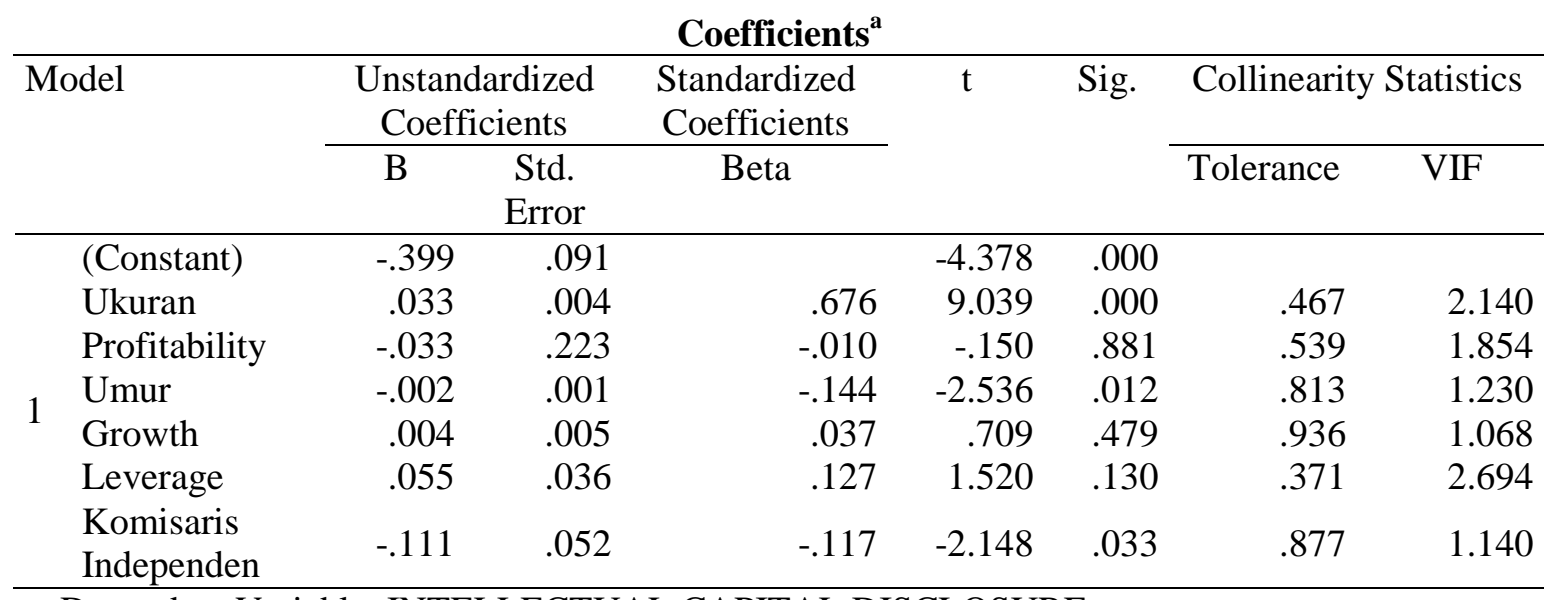

a. Dependent Variable: INTELLECTUAL CAPITAL DISCLOSURE

Berdasarkan Tabel 5 di atas dapat dilihat bahwa variabel firm size (ukuran perusahaan), profitability, firm age, firm growth, leverage, dan independent commissioner memiliki nilai tolerance $\geq 0,10$ dan nilai variance inflation factor $(V I F) \leq 10$. Dengan demikian dapat disimpulkan bahwa tidak terjadi multikolinieritas pada model regresi.

Pengujian untuk mengetahui ada tidaknya autokorelasi dalam penelitian ini menggunakan Lagrange Multiplier (LM test) dengan menggunakan sampel di atas 100 observasi. Autokorelasi terjadi apabila nilai signifikansi 0,05 dan apabila nilai signifikansi > 0,05 maka tidak terjadi autokorelasi. Berikut disajikan hasil pengujian autokorelasi:

Tabel 6. Hasil Pengujian Autokorelasi Tahun 2012-2014

\begin{tabular}{|c|c|c|c|c|c|c|}
\hline \multirow{2}{*}{\multicolumn{2}{|c|}{ Model }} & \multicolumn{3}{|c|}{ Coefficients $^{\mathbf{a}}$} & \multirow{3}{*}{$\mathrm{t}$} & \multirow{4}{*}{ Sig. } \\
\hline & & \multicolumn{2}{|c|}{$\begin{array}{c}\text { Unstandardized } \\
\text { Coefficients }\end{array}$} & \multirow{2}{*}{$\begin{array}{c}\begin{array}{c}\text { Standardized } \\
\text { Coefficients }\end{array} \\
\text { Beta }\end{array}$} & & \\
\hline & & B & Std. Error & & & \\
\hline \multirow{8}{*}{1} & (Constant) & -.002 & .091 & & -.019 & \\
\hline & UKURAN & .000 & .004 & -.006 & -.052 & .958 \\
\hline & PROFITABILITY & .026 & .222 & .013 & .119 & .905 \\
\hline & UMUR & .000 & .001 & .026 & .292 & .771 \\
\hline & GROWTH & .002 & .005 & .023 & .279 & .781 \\
\hline & LEVERAGE & -.003 & .036 & -.012 & -.095 & .925 \\
\hline & $\begin{array}{l}\text { KOMISARIS } \\
\text { INDEPENDEN }\end{array}$ & .004 & .051 & .007 & .087 & .931 \\
\hline & LAG2 & -.133 & .081 & -.134 & -1.646 & .102 \\
\hline
\end{tabular}

Dari uji autokorelasi diperoleh angka Lag2 0,102 seperti yang ditunjukkan pada Tabel 6, dimana angka $L M$ test $>0,05$. Hasil pengujian tersebut menunjukkan bahwa dalam model regresi tidak terdapat autokorelasi, yang berarti model regresi layak untuk digunakan dalam penelitian ini. 
Pengujian heteroskedastisitas dalam penelitian ini dilakukan dengan uji Spearman Rho. Data yang tidak terdapat heteroskedastisitas adalah yang memiliki nilai signifikansi melebihi tingkat keyakinan 5\%. Berikut disajikan hasil pengujian heteroskedastisitas:

Tabel 7. Hasil Pengujian Heteroskedastisitas Tahun 2012-2014

\begin{tabular}{|c|c|c|c|c|c|c|c|c|c|}
\hline \multicolumn{10}{|c|}{ Cunedaliuns } \\
\hline & & & LKJ) & 'ROFT:B J I & Liti: & $320 \% \pi 1$ & 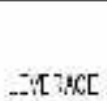 & $\begin{array}{c}\text { KOYMARS } \\
\text { NDEP=KCE } \\
\text { 1. }\end{array}$ & $\begin{array}{l}\text { Uns:arcarcie } \\
\text { z: Resi:.al }\end{array}$ \\
\hline \multirow[t]{21}{*}{ 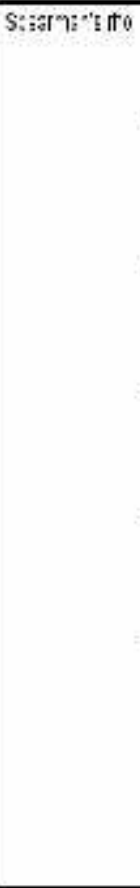 } & \multirow[t]{3}{*}{ L.J.JW: } & Con: alcr Cэatld:" & $1.25:$ & 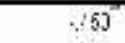 & $.13 \bar{i}$ & .22 & $.63^{\circ}$ & 23 & .023 \\
\hline & & St: 2 - 1 el & & rifi & nis & กn.5 & กตก & $\because$ & 717 \\
\hline & & k & 17 & 171 & 171 & 131 & 171 & 7 & 171 \\
\hline & \multirow[t]{3}{*}{ PZ): THEILT: } & Con: aler 3yriis:" & $A E C^{11}$ & 600 & .234 & .012 & $.732^{2}$ & $217^{\prime \prime}$ & .043 \\
\hline & & 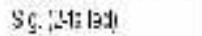 & JJ. & . & .003 & .896 & wou & $\ldots 1$ & bit \\
\hline & & i. & $1 \%$ & 171 & 171 & 171 & 171 & $\%$ & 171 \\
\hline & \multirow[t]{3}{*}{ I.WI.K } & 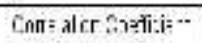 & 137 & 2NE & ำ? & - & . 12 & $-68^{-4}$ & n13 \\
\hline & & Sc. $22131=1$ & .374 & $C 00$ & : & .251 & 067 & $\therefore 6$ & .015 \\
\hline & & h. & $1 i^{\prime \prime}$ & 111 & 111 & 111 & 111 & $\because "$ & 111 \\
\hline & \multirow[t]{3}{*}{ GFCOTR } & 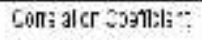 & 27 & C1: & .083 & .000 & 112 & $\therefore 1$ & .013 \\
\hline & & Ss.; $2-1=1 \leq 1 !$ &.$j \mathrm{~s}$ & 855 & .251 & ; & $1<6$ & $\therefore 5$ & .812 \\
\hline & & h & $17^{\prime}$ & 171 & 171 & 131 & 171 & $i$ & 171 \\
\hline & \multirow[t]{3}{*}{ ए;:[7\%: } & Con: aler Gaztis: :" & :" & $.792^{2}$ & .123 & .112 & 000 & $2 S 1$ & .022 \\
\hline & & 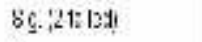 & $\mathrm{JJ}$. & CWU & $.06 i$ & .126 & . & $\therefore 6$ & .17 \\
\hline & & 1. & $1 \pi$ & 111 & 171 & 171 & 171 & $\%$ & 111 \\
\hline & \multirow{3}{*}{ 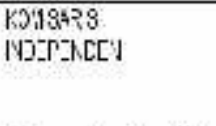 } & 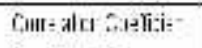 & 194 & .917 & $-19 \mathrm{E}^{\prime \prime}$ & Nit: & $37^{4}$ & \multirow[t]{2}{*}{$1 \% c$} & $m+\frac{\pi}{3}$ \\
\hline & & So. $2-2131=81$ & $.3 z_{i}$ & $\mathrm{CO}_{2}$ & .013 & .056 & 000 & & .935 \\
\hline & & h & 17 & 171 & 171 & 171 & 171 & 7 & 171 \\
\hline & \multirow[t]{3}{*}{ Lns1; carctadFesld, ; } & 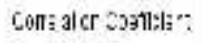 & $.32 i$ & $-\mathrm{C}: 3$ & .013 & .018 & 022 & $\therefore E$ & .003 \\
\hline & & 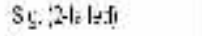 & $7:$ & 67 & .815 & .812 & 777 & .16 & . \\
\hline & & t. & 17: & 171 & 171 & 171 & tit & $\because$ & 171 \\
\hline
\end{tabular}

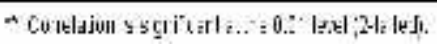

Berdasarkan Tabel 7 dapat dilihat bahwa variabel firm size memiliki nilai signifikansi 0,710, profitability memiliki nilai signifikansi 0,577 , firm age memiliki nilai signifikansi 0,815 , firm growth memiliki nilai signifikansi 0,812 , leverage memiliki nilai signifikansi 0,777, dan independent commissioner memiliki nilai signifikansi 0,936. Nilai signifikansi keenam variabel independen melebihi tingkat keyakinan 5\%, sehingga dapat disimpulkan bahwa model regresi tidak terdapat heteroskedastisitas. Berikut disajikan hasil uji korelasi dan koefisien determinasi:

Tabel 8. Hasil Pengujian Korelasi (R) dan Koefisien Determinasi (Adj R ${ }^{2}$ ) Tahun 20122014

\section{Model Summary ${ }^{\mathrm{b}}$}

\begin{tabular}{|c|c|c|c|}
\hline Model & $\mathrm{R}$ & Adjusted R Square & $\begin{array}{l}\text { Std. Error of the } \\
\text { Estimate }\end{array}$ \\
\hline 1 & $.756^{\mathrm{a}}$ & .556 & .07887 \\
\hline
\end{tabular}


Berdasarkan Tabel 8 diperoleh nilai korelasi (R) sebesar 0,756. Hal ini berarti bahwa hubungan antara variabel pengaruh firm size, profitability, firm age, firm growth, leverage, dan independent commissioner terhadap intellectual capital disclosure adalah hubungan yang kuat dan positif. Hal tersebut dapat dilihat dari nilai $\mathrm{R}$ yang semakin mendekati satu. Selain itu, juga diperoleh nilai koefisien determinasi sebesar 0,556. Berdasarkan hasil tersebut dapat disimpulkan bahwa sebesar 55,6\% variabel dependen yaitu intellectual capital disclosure dapat dijelaskan oleh variabel independen yaitu firm size, profitability, firm age, firm growth, leverage, dan independent commissioner sedangkan sisanya sebesar $44,4 \%$ dijelaskan oleh variabel-variabel lainnya yang tidak diungkapkan dalam penelitian ini.

Selanjutnya dilakukan pengujian $\mathrm{F}$ untuk mengetahui apakah variabel independen secara bersama-sama berpengaruh terhadap variabel dependen. Berikut ini disajikan hasil uji $\mathrm{F}$ dalam penelitian ini:

Tabel 9. Hasil Uji F

\begin{tabular}{rlrrrrr}
\multicolumn{7}{c}{ ANOVA $^{\mathrm{a}}$} \\
Model & & $\begin{array}{c}\text { Sum of } \\
\text { Squares }\end{array}$ & $\mathrm{df}$ & Mean Square & F & Sig. \\
\hline \multirow{3}{*}{1} & Regression & 1.363 & 6 & .227 & 36.530 & $.000^{\mathrm{b}}$ \\
& Residual & 1.020 & 164 & .006 & & \\
& Total & 2.384 & 170 & & & \\
\hline
\end{tabular}

a. Dependent Variable: Intellectual Capital Disclosure

b. Predictors: (Constant), Komisaris Independen, Growth, Leverage, Umur,

Profitability, Ukuran

Berdasarkan Tabel 9 dapat dilihat bahwa nilai signifikansi yang diperoleh adalah 0,000 dimana nilai tersebut lebih kecil dari 0,05. Berdasarkan hasil tersebut dapat disimpulkan bahwa model regresi dapat digunakan untuk memprediksi adanya pengungkapan modal intelektual dan variabel independen yaitu firm size, profitability, firm age, firm growth, leverage, dan independent commissioner secara bersama-sama berpengaruh terhadap pengungkapan modal intelektual.

Uji t pada dasarnya digunakan untuk mengetahui pengaruh firm size, profitability, firm age, firm growth, leverage, dan independent commissioner terhadap intellectual capital disclosure secara parsial. Berikut disajikan hasil uji t:

Tabel 10. Hasil Uji t

\begin{tabular}{|c|c|c|c|c|c|c|}
\hline & & Coeff & ients ${ }^{a}$ & & & \\
\hline & & Unstan & ardized & Standardized & $\mathrm{t}$ & Sig. \\
\hline & & $\mathrm{B}$ & Std. Error & Beta & & \\
\hline & (Constant) & -.399 & .091 & & -4.378 & .000 \\
\hline & Ukuran & .033 & .004 & .676 & 9.039 & .000 \\
\hline & Profitability & -.033 & .223 & -.010 & -.150 & .881 \\
\hline 1 & Umur & -.002 & .001 & -.144 & -2.536 & .012 \\
\hline & Growth & .004 & .005 & .037 & .709 & .479 \\
\hline & Leverage & .055 & .036 & .127 & 1.520 & .130 \\
\hline & Komisaris Independen & -.111 & .052 & -.117 & -2.148 & .033 \\
\hline
\end{tabular}


Berdasarkan Tabel 10 dapat diketahui persamaan model regresi berganda adalah sebagai berikut:

$$
\text { ICD }=-0,399+0,033 \mathrm{X} 1-0,033 \mathrm{X} 2-0,002 \mathrm{X} 3+0,004 \mathrm{X} 4+0,055 \mathrm{X} 5-0,111 \mathrm{X} 6+\mathrm{e}
$$

Dari Tabel 10, terlihat bahwa variabel firm size memiliki nilai signifikansi 0,000 . Hasil ini lebih kecil dari tingkat signifikansi 0,05. Oleh karena itu, H1 tidak ditolak yang berarti terdapat pengaruh signifikan antara variabel firm size terhadap intellectual capital disclosure dengan tingkat keyakinan $95 \%$.

Hasil penelitian ini sesuai dengan hasil penelitian Purnomosidhi (2006), White, Lee, dan Tower (2007), Bruggen, Vergauwen, dan Dao (2009), Windri dan Januarti (2010), Suhardjanto dan Wardhani (2010), Taliyang, Latif dan Mustafa (2011), Stephani dan Yuyetta (2011), Ferreira, Branco, dan Moreira (2012), Lina (2013), serta Oktavianti dan Wahidahwati (2014) yang menyatakan bahwa firm size memiliki pengaruh terhadap intellectual capital disclosure. Hasil penelitian ini bertentangan dengan Nugroho (2012) serta Sudarmadji dan Sularto (2007) yang menyatakan bahwa firm size tidak memiliki pengaruh terhadap intellectual capital disclosure. Hasil penelitian ini mendukung agency theory yang menyatakan bahwa semakin besar ukuran perusahaan maka lebih banyak dituntut oleh publik untuk menyediakan informasi yang lebih baik dibandingkan dengan perusahaan yang lebih kecil, maka monitoring cost yang dikeluarkan akan lebih besar, termasuk pengungkapan mengenai modal intelektual agar dapat meminimalkan monitoring cost.

Variabel Profitability memiliki nilai signifikansi 0,881. Hasil ini lebih besar dari tingkat signifikansi 0,05 . Oleh karena itu, $\mathrm{H} 2$ ditolak yang berarti tidak terdapat pengaruh signifikan antara variabel Profitability terhadap intellectual capital disclosure dengan tingkat keyakinan $95 \%$.

Hasil penelitian ini sesuai dengan hasil penelitian Purnomosidhi (2006), Sudarmadji dan Sularto (2007), Taliyang, Latif dan Mustafa (2011), Stephani dan Yuyetta (2011), Ferreira, Branco, dan Moreira (2012), serta Lina (2013), yang menyatakan bahwa profitability tidak memiliki pengaruh terhadap intellectual capital disclosure. Hasil penelitian ini bertentangan dengan Oktavianti dan Wahidahwati (2014) serta Suhardjanto dan Wardhani (2010) yang menyatakan bahwa profitability memiliki pengaruh terhadap intellectual capital disclosure. Hal ini dikarenakan profit/keuntungan yang dihasilkan oleh perusahaan merupakan salah satu cerminan kinerja perusahaan sehingga tidak akan berdampak pada pengungkapan modal intelektual.

Variabel firm age memiliki nilai signifikansi 0,012. Hasil ini lebih kecil dari tingkat signifikansi 0,05 . Oleh karena itu, H3 tidak ditolak yang berarti terdapat pengaruh signifikan antara variabel firm age terhadap intellectual capital disclosure dengan tingkat keyakinan $95 \%$.

Hasil penelitian ini sesuai dengan hasil penelitian Taliyang, Latif dan Mustafa (2011) serta Lina (2013), yang menyatakan bahwa firm age memiliki pengaruh terhadap intellectual capital disclosure. Hasil penelitian ini bertentangan dengan White, Lee, dan Tower (2007), Stephani dan Yuyetta (2011), serta Nugroho (2012) yang menyatakan bahwa firm age tidak memiliki pengaruh terhadap intellectual capital disclosure. Hal ini dikarenakan menurut Ulum (2009) semakin lama umur perusahaan belum tentu semakin baik tingkat pengalaman dan pemahamannya terkait dengan intellectual capital yang dimiliki oleh suatu perusahaan, sehingga tingkat pengungkapan intellectual capital tidak bisa optimal. 
Variabel Firm growth memiliki nilai signifikansi 0,479. Hasil ini lebih besar dari tingkat signifikansi 0,05 . Oleh karena itu, $\mathrm{H} 4$ ditolak yang berarti tidak terdapat pengaruh signifikan antara variabel Firm growth terhadap intellectual capital disclosure dengan tingkat keyakinan $95 \%$.

Hasil penelitian ini sesuai dengan hasil penelitian Lina (2013) yang menyatakan bahwa firm growth tidak memiliki pengaruh terhadap intellectual capital disclosure. Hasil penelitian ini bertentangan dengan Taliyang, Latif dan Mustafa (2011) yang menyatakan bahwa firm growth memiliki pengaruh terhadap intellectual capital disclosure. Hal ini dikarenakan jika dilihat dari kondisi perusahaan, baik perusahaan sedang bertumbuh maupun tidak, tidak akan mempengaruhi suatu perusahaan untuk mengungkapkan lebih luas atas modal intelektual karena modal intelektual merupakan tuntutan dari external stakeholders tanpa memperdulikan kondisi suatu perusahaan.

Variabel Leverage memiliki nilai signifikansi 0,130. Hasil ini lebih besar dari tingkat signifikansi 0,05. Oleh karena itu, H5 ditolak yang berarti tidak terdapat pengaruh signifikan antara variabel leverage terhadap intellectual capital disclosure dengan tingkat keyakinan $95 \%$.

Hasil penelitian ini sesuai dengan hasil penelitian Sudarmadji dan Sularto (2007), Suhardjanto dan Wardhani (2010), Windri dan Januarti (2010), Taliyang, Latif dan Mustafa (2011), Ferreira, Branco, dan Moreira (2012), Nugroho (2012), serta Oktavianti dan Wahidahwati (2014) yang menyatakan bahwa leverage tidak memiliki pengaruh terhadap intellectual capital disclosure. Hasil penelitian ini bertentangan dengan White, Lee, dan Tower (2007), serta Stephani dan Yuyetta (2011), yang menyatakan bahwa leverage memiliki pengaruh terhadap intellectual capital disclosure. Leverage bukan menjadi salah satu faktor yang mempengaruhi pengungkapan intellectual capital karena perusahaan ingin menjaga citra, nama baik, dan reputasi perusahaan sehingga ketidakoptimalan dalam pengelolaan rasio leverage tidak banyak diketahui oleh pihak eksternal. Hal ini disebabkan pada umumnya perusahaan yang mempunyai tingkat hutang yang tinggi cenderung memiliki kondisi keuangan yang kurang baik. Langkah yang perlu dilakukan perusahaan adalah dengan cara mengurangi tingkat pengungkapan agar tidak menjadi sorotan dari para debtholder.

Variabel Independent Commissioner memiliki nilai signifikansi 0,033. Hasil ini lebih kecil dari tingkat signifikansi 0,05. Oleh karena itu, H6 tidak ditolak yang berarti terdapat pengaruh signifikan antara variabel Independent Commissioner terhadap intellectual capital disclosure dengan tingkat keyakinan $95 \%$.

Hasil penelitian ini sesuai dengan hasil penelitian White, Lee, dan Tower (2007) serta Li, Pike dan Haniffa (2008) yang menyatakan bahwa Independent Commissioner memiliki pengaruh terhadap intellectual capital disclosure. Hasil penelitian ini bertentangan dengan Suhardjanto dan Wardhani (2010), Nugroho (2012), serta Oktavianti dan Wahidahwati (2014) yang menyatakan bahwa Independent Commissioner tidak memiliki pengaruh terhadap intellectual capital disclosure. Komisaris independen merupakan pihak yang netral dalam perusahaan guna untuk meminimalkan asimetri informasi yang terjadi antara pihak pemilik dan pihak manajer sehingga di perusahaan besar, komisaris independen lebih dipercaya untuk membantu pihak manajemen untuk mengungkapkan modal intelektual yang lebih komprehensif. 


\section{PENUTUP}

Simpulan. Penelitian ini dilakukan terhadap 57 perusahaan sektor keuangan yang terdaftar di Bursa Efek Indonesia (BEI) pada periode 2012-2014. Pengolahan data dalam penelitian ini menggunakan program SPSS 20.00.

Model yang digunakan untuk menguji hipotesis adalah model regresi linear berganda. Hasil penelitian menunjukkan bahwa variabel independen dan variabel dependen telah memenuhi persyaratan uji normalitas, uji multikolineritas, uji autokorelasi, dan uji heteroskedastisitas. Hasil pengujian menunjukkan bahwa firms size, firm age, dan independent commissioner berpengaruh secara parsial terhadap intellectual capital disclosure, sedangkan profitability, firm growth, dan leverage secara parsial tidak berpengaruh terhadap intellectual capital disclosure.

Saran. Untuk penelitian selanjutnya, dapat dilakukan penambahan variabel independen seperti ownership concentration, length of listing, tipe industri dan tipe auditor.

\section{DAFTAR RUJUKAN}

Bruggen, Alexander, Philip Vergauwen, dan Mai Dao. (2009) "Determinants of Intellectual Capital Disclosure: evidence from Australia". Management Decision. Vol. 47 (2) hal. 233-245

Fahmi, Irham. (2014) Manajemen Keuangan Perusahaan dan Pasar Modal. Jakarta: Mitra Wacana Media

Ferreira, Ana Lucia, Manuel Castela Branco, dan Jose Antonio Moreira. (2012) "Factors influencing intellectual capital disclosure by Portuguese companies". International Journal of Accounting and Financial Reporting. Vol. 2 (2) hal. 278-298

Firer, Steven and S. Mitchell Williams. (2003) "Intellectual Capital and Traditional Measure of Corporate Performance". Journal of Intellectual Capital. 4 (3) hal 348360

Kieso, E Donald, Weygandt, Jerry J, and Paul D. Kimmel. (2013) Financial Accounting. IFRS $2^{\text {nd }}$ edition. New Jersey: John Wiley \& Sons, Inc

Li, Jing, Richard Pike, dan Roszaini Haniffa (2008) "Intellectual capital disclosure and corporate governance structure in UK firms". Accounting and Business Research. Vol. 38 (2) hal. 137-159

Lina. (2013) "Faktor-faktor penentu pengungkapan modal intelektual". Media Riset \& Akuntansi. Vol. 3 (1) hal. 48-64

Nugroho, Ahmadi. (2012) "Faktor-faktor yang mempengaruhi Intellectual Capital Disclosure (ICD)". Accounting Analysis Journal. Vol. 1 (2) hal. 2-11

Oktavianti, Heni dan Wahidahwati. (2014) "Faktor-faktor yang mempengaruhi pengungkapan intellectual capital". Journal Ilmu \& Riset Akuntansi. Vol. 3 (1) hal. 48-64

Purnomosidhi, Bambang. (2006) "Praktik pengungkapan modal intelektual pada perusahaan publik di BEJ". Jurnal Riset Akuntansi Indonesia. Vol. 9 (1) hal 1-20

Schroeder, Richard G., Myrtle W. Clark, dan Jack M. Cathey. (2013) Financial accounting theory and analysis: text and cases. $11^{\text {th }}$ edition. United State of America: John Wiley and Sons 
Scott, William R. (2014) Financial accounting theory. $7^{\text {th }}$ edition. University of Waterloo. Toronto: Pearson

Sir, Jennie, Bambang Subroto, dan Grahita Chandrarin. (2010) Intellectual capital dan abnormal return saham. Simposium Nasional Akuntansi XIII Purwokerto.Hal. 1-27

Stephani, Thresya dan Etna Nur Afri Yuyetta. (2011) "Analisis faktor-faktor yang mempengaruhi Intellectual Capital Disclosure (ICD)". Jurnal Akuntansi \& Auditing. Vol. 7 (2) hal. 111-121

Sudarmadji, Ardi Muroko dan Lana Sularto. (2007) "Pengaruh ukuran perusahaan, profitabilitas, leverage dan tipe kepemilikan perusahaan terhadap luas voluntary disclosure laporan keuangan tahunan". Proceeding PESAT. Vol. 2. A53-61

Suhardjanto, Djoko dan Mari Wardhani. (2010) "Praktik Intellectual Capital Disclosure perusahaan yang terdaftar di Bursa Efek Indonesia”. JAAI. Vol. 14 (1) hal. 71-85

Taliyang, Siti Mariana, Rohaida Abdul Latif, dan Nurul Huda Mustafa. (2011) "The determinants of Intellectual Capital Disclosure among malaysian listed companies". International Journal Of Management And Marketing Research. Vol. 4 (3) hal. 2533

Ulum, Ihyaul. (2009) Intellectual Capital: Kinerja dan Kajian Empiris. Yogyakarta: Graha Ilmu

White, Gregory, Alina Lee, dan Greg Tower. (2007) "Drivers of voluntary intellectual capital disclosure by Australian companies". Journal of Intellectual Capital. Vol. 8 (3) hal. 517-537

Wijana A.P., Nyoman, Sutrisno M. Achsin, dan Wirakusuma. (2013) "The Voluntary disclosure of intellectual capital: longitudinal study from public firms in Indonesia". Research Journal of Finance and Accounting. Vol. 4 (12) hal. 38-46

Windri dan Indira Januarti. (2010) "Pengaruh kinerja intellectual capital terhadap kinerja intellectual capital pada perusahaan manufaktur yang terdaftar di BEI". Jurnal Akuntansi \& Auditing. Vol. 7 (1) hal. 49-61 